From: ClINICAL ASPECTS OF NEUTRON CAPTURE THERAPY Edited by Ralph G. Fairchild, Victor P. Bond,

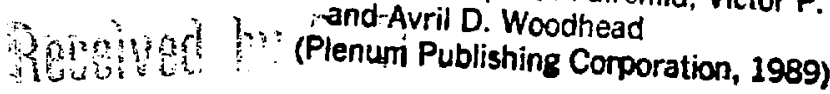

\title{
OCT 171989
}

NEUTRON CAPTURE THERAPY FOR MELANOMA

Jeffrey A. Coderre, John D. Glass, Peggy Micca and Ralph G. Falrchild

Medical Department

Brookhaven National Laboratory

Upton, N.Y. 11973

\section{INTRODUCTION}

The dose-limiting factor in cancer radiation therapy is the tolerance level of normal tissues within the radiation field. In boron neutron capture therapy (BNCT), thermal neutrons interact with boron via the $10_{B}(n, \alpha) T_{L 1}$ reaction (Taylor, 1935) to produce short-range ( 5-9 $\mu \mathrm{m})$, high-linear energy transfer radiations which have a large relative biological effectiveness (RBE) (Gabel, 1984; Fukuda, 1987). In theory, selective localization of $10_{B}$ within the tumor should allow most of the dose to be restricted to the tumor (Locher, 1936). The failure of the initial clinical trlals of BNCT, carrled out between 1953 and 1961 at Brookhaven National Laboratory and the Massachusetts General Hospital (Farr, 1954; Goodwin, 1955; Asbury, 1972) was attributed to two major factors: (1) the use of boron-containing compounds which showed no selective accumulation in tumor and (il) the rapid attenuation in tissue of the incident thermal neutron beam. The high neutron doses employed resulted in excessive surface tissue exposure; viable tumor was found at depth following the neutron irradiations. The substantial levels of boron in blood during irradiation contributed to the damage to normal brain vasculature (tumor/blood ratio $(1)$.

The development of boron-containing compounds which localize selectively in tumor may require a tumor-by-tumor type of approach that exploits any metabolic pathways unique to the particular type of tumor. Melanin-producing melanomas actively transport and metabolize aromatic amino acids for use as precursors in the synthesis of the pigment melanin. It has been shown that the boron- 
containing amino acid analog p-borono-phenylalanine (BPA) is selectively accumulated in melanoma tissue, producing boron concentrations in tumor that are within the range estimated to be necessary for successful BNCT (Mishima, 1983; Coderre, 1987). We report here the results of therapy experiments carried out at the Brookhaven Medical Research Reactor (BMRR).

\section{METHODS}

\section{Murine Melanoma}

Adult female BALB/c mice $(\sim 15-20 \mathrm{~g}$ ) in which the HardingPassey melanoma had been implanted subcutaneously on either the abdomen or the thigh were used. This tumor has been maintained in our laboratory by serial transplantation for over 10 years and is reproducible with respect to melanin content and uptake of melanin affinic agents. Melanin content ( $0.68 \%$ melanin by weight) is analogous to that found in human melanotic melanoma ( 0.1 to $0.8 \%$; average value, $0.35 \%$ ) (Watts, 1981). The Harding-Passey melanoma does not metastasize but grows at the original subcutaneous implantation site with a volume doubling time of about 3 days. The subcutaneous location of this heavily pigmented tumor facilitates volume measurements. For therapy experiments, tumors between 30 and $100 \mathrm{mg}$ in size were chosen; this size corresponds to 14-18 days of growth. Tumors which have grown to this size do not undergo spontaneous remission. Mice with untreated tumors or mice with tumors which eventually resumed growth following the irradiation procedures were sacrificed when the tumors became unnecessarily large (approximately $2-3 \mathrm{~cm}^{3}$ ). Mice whose tumors did not regrow after therapy were monitored until they became incapacitated by old age near the end of a normal lifespan ( 18 months).

\section{BMRR Dosimetry}

The BMRR is a 5-MW modified, pool-type nuclear reactor designed for biomedical research (Godel, 1960). The BMRR has been the site of numerous BNCT experinents; the irradiations described here were done at the BMRR patient port. Fast neutron and gamma doses were measured directly using standard tissue equivalent and graphite- $\mathrm{CO}_{2}$ chambers as well as TLD-700 dosimeters (Robertson, 1972; Fairchild, 1966). Contributions from the $14 \mathrm{~N}(\mathrm{n}, \mathrm{p})^{14} \mathrm{C}$ and ${ }_{10} 0_{B}(n, a)^{7} L_{1}$ reactions were calculated from gold foil measurements of thermal neutron flux density and corrected for resonance response by the cadmium difference technique (Beckurts, 1964).

\section{Irradiation Procedures}

During Irradiations, mice were anesthetized with sodium pentabarbital (65 $\mathrm{\mu g} / \mathrm{g}$ body weight via $1 . \mathrm{p}$. injection). To evaluate 
the radiosensitivity of the Harding-Passey melanoma to conventional $x$ rays, mice bearing thigh tumors were irradiated with a Phillips RT-100 superficial $x$-ray machine using $100 \mathrm{kVp} x$ rays (1.7 mm Al added filtration) at a dose rate of $1000 \mathrm{rad}$ per min. The tumor-bearing region of the thigh was exposed directly, the body and foot were shielded with lead.

For neutron irradiations, the BMRR patient port thermal beam $(25 \times 25 \mathrm{~cm}$ ) was restricted to $1.5-\mathrm{cm}$ diameter using an insert of 1:I 6 LiF mixed with epoxy resin molded to collimate the beam at the port center. Additional body shielding was provided by sheets of lithium metal in oil-filled plastic bags. The turor-bearing leg was extended over the $1.5-\mathrm{cm}$ beam port during 1rradiation. Neutron exposures ranged from 2.5 to $6.7 \times 10^{12} \mathrm{n} / \mathrm{cm}^{2}$.

Therapeutic Endpoint

The endpoint used to assess the effectiveness of the tumor irradiations was a determination of tumor growth delay or tumor control. Tumor size was measured daily following irradiation. Tumor volumes were estimated by the formula $v=0.5 a b^{2}$, where a and $b$ are the longest and shortest diameters, respectively (Rofstad, 1985). Tumor volumes were normalized to the volume on the day of irradiation, then averaged for each group. Irradiated tumors exhibited a longer volume doubling time and, at higher doses, a lag perlod of no growth followed by a resumption of growth at a slower rate than unirradiated controls. Tumors showIng apparent growth control, following irradiation, were monitored for subsequent regrowth during the residual lifespan of the mouse. Tumor growth control was considered complete only if the mouse Iived out its residual lifespan (over I year) with no evidence of tumor regrowth.

\section{RESULTS AND DISCUSSION}

Distribution studies

We have recently described the results of our tumor uptake and distribution studies (Coderre, 1987). Using the HardingPassey melanoma cerryling s.c. In BALB/c mice, we have demonstrated that BPA is taken up by melanoma tissue to a much greater extent than by normal tissues. Following a single i.p. injection or a series of injections given over $1 \mathrm{~h}$, the accumulation of boron in melanoma was found to be transient, reaching a maximum approximately $6 \mathrm{~h}$ post-injection. The concentrations of boron achieved in tumor ranged from $9-33 \mu \mathrm{g} / \mathrm{g}$ and are within the range estimated to be necessary for successful application of the nuclear reaction ${ }^{10} 0_{B}(n, \alpha)^{7} \mathrm{~L} 1$ for neutron capture therapy. Boron concentrations in tumor and tissues were determined using either a prompt-gamma 
spectroscopic technique or by quantitative neutron capture radiography using whole-body sections. Distribution studies with the resolved stereoisomers of BPA indicated that the $L$ isomer is preferentially accumulated in the melanoma compared to the $D$ isomer (see Figure 1). The $\mathrm{L}$ 1 somer of $\mathrm{BPA}$ was shown to be targeted to actively dividing tumor cells by simultaneously comparing the boron and $\left[3_{\mathrm{H}}\right]$ thymidine $\left(\left[{ }^{3} \mathrm{H}\right] \mathrm{Thd}\right.$ ) distribution in tumor (see Figure 2).

\section{Toxicity of BPA}

BPA is not toxic. We have been unable to deliver a lethal dose of BPA to mice by normal means. The solubility of BPA at $\mathrm{pH}$ values which are tolerated physiologically is about $6 \mathrm{mg} / \mathrm{ml}$. Volume limits the amount that can be administered. At this concentration, $i . v$. injections are 1 imited to roughly $3 \mathrm{mg}(150 \mathrm{mg} / \mathrm{kg}$ body weight). Using i.p. injections, we have been able to administer $6 \mathrm{mg}$ ( $1-\mathrm{m} 1 \mathrm{i} . \mathrm{p}$. injection) or up to $12 \mathrm{mg}$ (four $0.5-\mathrm{ml}$ i.p. injections over the course of $1 \mathrm{~h}$ ). Even at the highest i.p. dose of $12 \mathrm{mg}(600 \mathrm{mg} / \mathrm{kg})$, no toxic effects were observed.
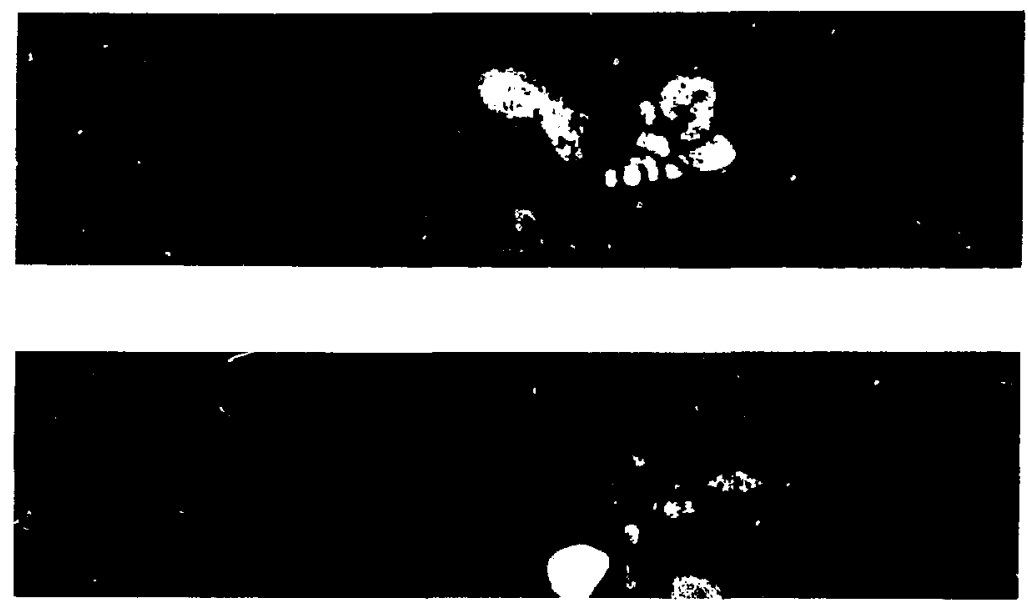

Fig. 1. Distribution of L-BPA vs. D-BPA. Tunor-bearing mice given injections of $D-\overline{B P A}$ or L-BPA, sacrificed $6 \mathrm{~h}$ postinjection; whole-body sections preparad; neutron capture radiograms shown. Top, D-BPA containing natural abundance boron; neutron fivence $-6.0 \times 10^{12} \mathrm{n} / \mathrm{cm}^{2}$. Bottom,

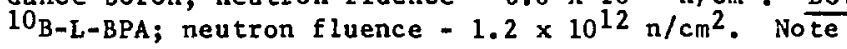
preferential accumulation of L-BPA in melanoma. 

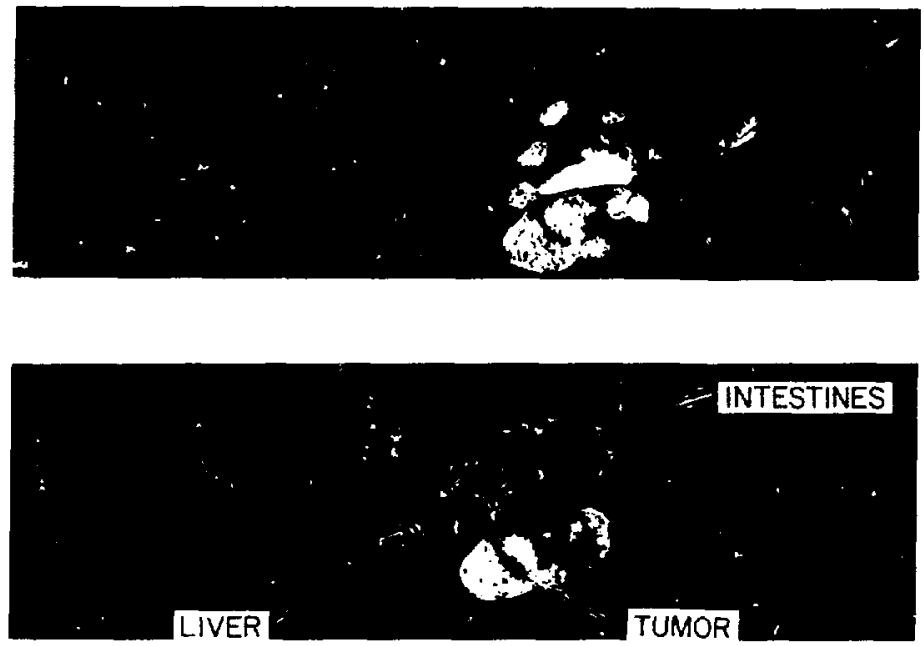

Fig. 2. Double labeling with boron and $\left[{ }^{3} \mathrm{H}\right]$ Thd. Tumor-bearing

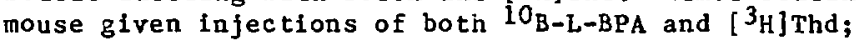
whole-body sections prepared. Top, neutron capture radiogram prepared from whole-body section. Neutron fluence used to generate this image $-2.4 \times 10^{12} \mathrm{n} / \mathrm{cm}^{2}$. Bottom, [ $\left.{ }^{3} \mathrm{H}\right]$ Thd autoradiogram prepared from same wholebody section used for neutron capture radiogram. Hote highest concentrations of boron in tumor correspond closely with areas of rapid cell division identified by $\left[{ }^{3} \mathrm{H}\right] \mathrm{Thd}$ incorporation.

\section{Oral Dose}

Since our distribution data indicated that bolus injections were most effective, we have recently begun using oral administration of BPA as a slurry in water to deliver as much as possible in a single dose. The time course for tumor uptake was similar to i.p. injections; at $6 \mathrm{~h}$ post- (oral) injection, the tumor values were maximal. The amount of $B P A$ that can be delivered orally is now increased to a maximum of $40 \mathrm{mg}(2000 \mathrm{mg} / \mathrm{kg}\rangle$. Even at this high oral dose of $40 \mathrm{mg}$, BPA was not toxic. This is in contradiction to previously published reports for the $L_{50}$ of $B P A$ of 1600 $\mathrm{mg} / \mathrm{kg}$ (Soloway, 1961) and $840 \mathrm{mg} / \mathrm{kg}$ (i1shima, 1980) administered i.p. These values were obtained using aqueous solutions of BPA at a pH of 10 and 3 , respectively, in order to increase the solubility. The observed toxicities were probably due to the extremes of pH utilized. 
Table 1. Boron content of tissues ( $\mu \mathrm{g} / g$ ) following an oral dose of BPA

\begin{tabular}{lllllll}
\hline No. of Mice & Blood & Tumor & Muscle & $T / B$ & $T / M$ \\
& & & & & & \\
& & & & & & \\
$\mathbf{n}=2$ & $3.1 \pm 0.8$ & $23.8 \pm 3.2$ & $5.1 \pm 0.7$ & 7.7 & 4.7 \\
$\mathbf{n}=5$ & $7.6 \pm 2.3$ & $41.1 \pm 2.1$ & $8.7 \pm 2.1$ & 5.4 & 4.7 \\
\hline
\end{tabular}

Using a standard dose of $15 \mathrm{mg} 10_{\mathrm{B}-\mathrm{L}-\mathrm{BPA}}$ in $0.5 \mathrm{ml}$ water, sacrifice at $6 \mathrm{~h}$, we have been able to increase the boron concentration in the tumor considerably. Table 1 sumnarizes these results.

\section{Therapy Experiments}

Table 2 summarizes the dosimetry calculations for the mouse leg irradiations at the BMRR. The total dose to the tumor during $B N C T$ depends on the $10_{B}$ concentrations in the tumor. The contribution to the dose from the $10_{\mathrm{B}}(\mathrm{n}, \alpha)^{7} \mathrm{Li}$ reaction was calculated by assuming $15 \mu g 10_{\mathrm{B}} / \mathrm{g}$ tumor; actual boron concentrations in tumor varied from 15-30 $\mathrm{\mu g} / \mathrm{g}$ (Coderre, 1987). Using the dose estimates given in Table 2, exposure times at the BMRR were chosen to give total doses in the therapeutic range. The BMRR operating power was 1 megawatt (MW); exposure times were 3,6 , and 8 minutes (the corresponding fluences were $2.0,5.0$, and $6.7 \times 10^{12} \mathrm{n} / \mathrm{cm}^{2}$, respectively). The doses to normal tissue within the neutron field at these exposure times were 234,468 , and 624 (rad $x$ RBE), respectively. (Absorbed dose in a mixed radiation field is expressed as effective dose (rad $x$ RBE), due to the different relative biological effectiveness ( $R B E$ ) of the component radiations). The corresponding doses to tumor, assuming a $10_{B}$ concentration of $15 \mu \mathrm{g} / \mathrm{g}$, are 1020,2040 , and 2720 ( $\mathrm{rad} \times \mathrm{RBE})$. The whole-body doses were 144,288 and 384 (rad $x$ RBE).

Preliminary BNCT experinents using BPA and the conditions outlined above indicated that irradiation for 3 iW-minutes produced only transient growth delayj, whereas, 6 and 8 MW-minute exposures resulted in significant tumor growth delays ( $>4$ weeks), as compared io irradiated controls, while still holding the wholebody dose within tolerable Iimits.

Figures 3 and 4 show the results of BNCT experiments carried out at the BMRR with exposure times of 6 and 8 MW-minutes, respec- 
Table 2. Dosimetry for mouse irradiations at the BMRR. Irradiations and dosimetry measurements using a ${ }^{6}$ LiF/epoxy $(1: 1)$ collimator with a $1.5-\mathrm{cm}$ cone aperture; reactor power, $1 \mathrm{MH}$.

$\begin{array}{ccc}\text { Dose Rate } & & \text { Effective } \\ \text { Dose Rate } \\ \text { Component }\end{array} \quad \begin{gathered}\text { (rad/min) } \\ (\operatorname{radxRBE} / \mathrm{min})\end{gathered}$

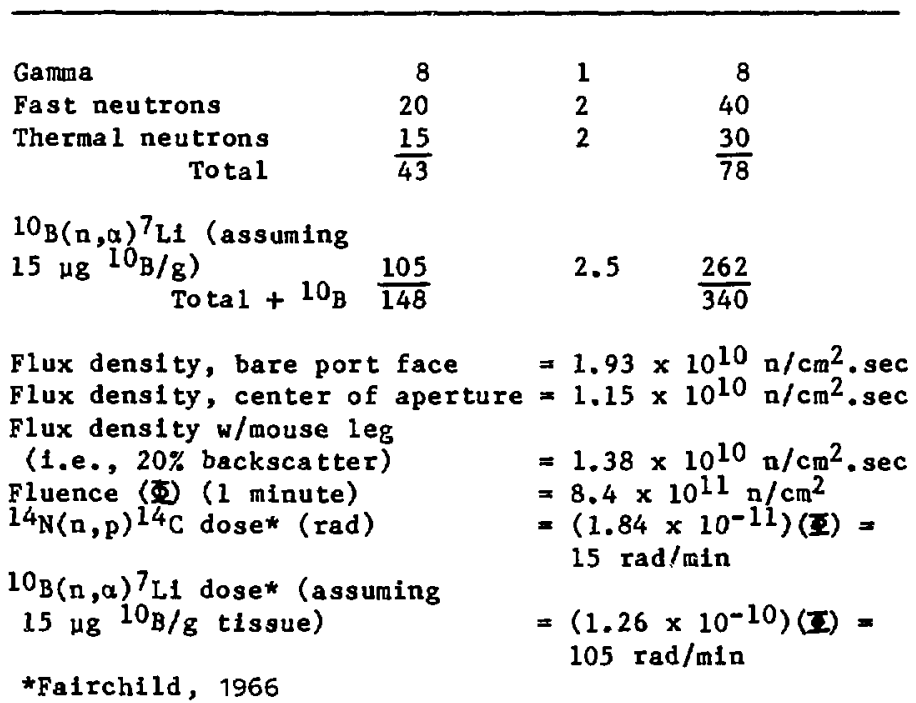

tively. Tumor volumes were normalized to the day of irradiation; each line is the average of 6 mice. Irradiation in the absence of $10_{B}$ delivers a dose sufficlent to delay tumor growth (5 and 6 weeks for 6 and $8 \mathrm{MW}-m i n u t e s$, respectively), but a 11 "neutrons only" controls eventually regrew. In the $6 \mathrm{MW}-m$ inute experiment shown in Figure 3, neutron irradiation in the presence of BPA produced growth delays of from 5 to 7 weeks, yet all of these tumors also eventually regrew. At $3 \mathrm{MW}$-minutes (Flgure 4), however, of the 6 BPA-containing tumors, 3 resumed growth after delays of from 7 to 10 weeks, but the remalning 3 showed complete tumor growth control, surviving for over 1 year with no sign of tumor regrowth. Figure 5 shows the individual growth data for the 6 tumors in the "neu irons + BPA" group in Figure 4. 


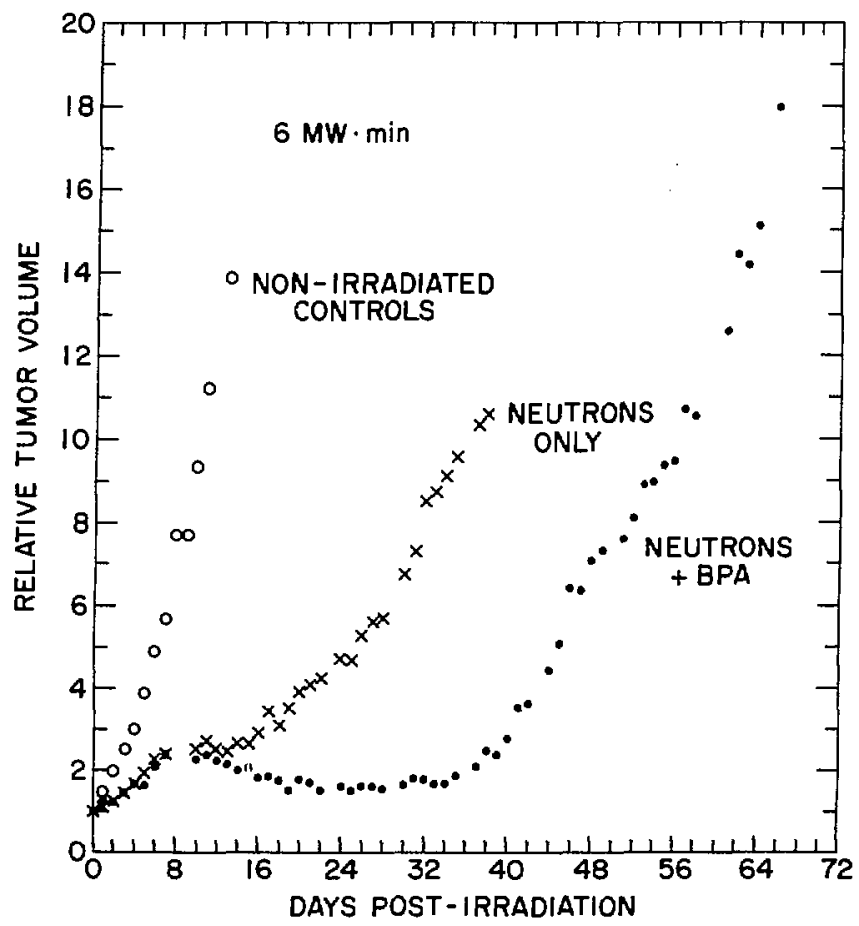

Fig. 3. BNCT at BMRR; neutron fluence $-5.0 \times 10^{12} \mathrm{n} / \mathrm{cm}^{-2}$. $B A L B / C$ mice bearing Harding-Passey melanoma subcutaneously on thigh each received $12 \mathrm{mg} B P A$ (four $0.5-\mathrm{ml}$ injections $/ 1 \mathrm{~h}$ ); irradiated $6 \mathrm{~h}$ after final injection. Each 1 ine $=$ average 6 mice. Tumor volumes normalized to day of irradiation. Tumor dose, neutrons only $=468$ ( $\operatorname{rad} \times \mathrm{RBE})$. Tumor dose, neutrons $+\mathrm{BPA}=2040(\mathrm{rad} \times$ RBE). Whole-body dose $=288$ ( $\mathrm{rad} \times \mathrm{RBE})$.

The experiments described here show that the response of the Harding-Passey melanoma to BNCT after a fixed course of BPA infections was directly related to the neutron fluence; increasing the exposure time resulted in longer tumor growth delays. At the highest neutron fluence utilized, $6.7 \times 10^{12} \mathrm{n} / \mathrm{cm}^{2}$ ( $8 \mathrm{MH}$-minutes), 3 of 6 treated tumors regressed completely and did not regrow during the remainder of the mouse's lifespan. The calculated absorbed dose for the tumor at this exposure level was 2720 ( $\mathrm{rad} x$ 
Table 3. BNCT using BPA and the Harding-Passey Melanoma in $\mathrm{BALB} / \mathrm{C} \mathrm{Mice}$

No. of mice Dose Neutron Exposure ${ }^{a}$ Positive responseb

$\begin{array}{llll}6^{\mathrm{c}} & 12 \mathrm{mg} \text { i.p. } & 6 \mathrm{MW}-\mathrm{min} & 0 / 6 \\ 6^{\mathrm{d}} & 12 \mathrm{mg} \text { 1.p. } & 8 \mathrm{MW}-\mathrm{min} & 3 / 6 \\ 8 & 15 \mathrm{mg} \text { oral } & 8 \mathrm{MW}-\mathrm{min} & 7 / 8 \\ 6 & 15 \mathrm{mg} \text { oral } & 6 \mathrm{MW}-\mathrm{min} & 5 / 6\end{array}$

a One megawatt minute (MW-min) corresponds to a neutron fluence of $8.4 \times 10^{11} \mathrm{n} / \mathrm{cm}^{2}$

$\mathrm{b}_{\mathrm{To}}$ be counted as a positive response, the tumors must undergo complete and permanent regression.

CResults 11lustrated in Figure 3.

$d_{\text {Results }} 1$ llustrated in Figures 4 and 5 .

RBE). This apparently curative dose is in concordance with the observed sensitivity of the Harding-Passey melanoma to $100 \mathrm{kVp} x$ rays. The $x$-ray dose required to cure $50 \%$ of treated tumors was ebout $3000 \mathrm{rad}$. The absorbed dose to the tumor in control mice that received no $B P A$ was 624 ( rad $x$ RBE). The effect of the BPA treatment was, therefore, to increase the effective radiation dose to the tumor by about 4.4 relative to controls which received no BPA prior to irradiation. The therapeutic gain or ratio of tumor dose to normal tissue dose within the treatment volume was $~ 3.3$, assuming a tumor/normal tissue boron distribution of 10 to 1 . It should be noted that this radiation enhancement was achleved unevenly over the tumor with the highest effective radiation doses concentrated in the most actively growing areas of the tumor. The growth rates of unirradiated tumors were unaffected by administration of BPA.

\section{Additional Therapy Experiments}

Using the oral delivery method for BPA, higher boron concentrations can be achieved in the tumor $\left(25-45 \mu \mathrm{g} 10_{\mathrm{B} / \mathrm{g}}\right)$. Therapy experiments are summarized in Table 3 which illustrate the greater effectiveness of BNCT following the oral doses of BPA. 


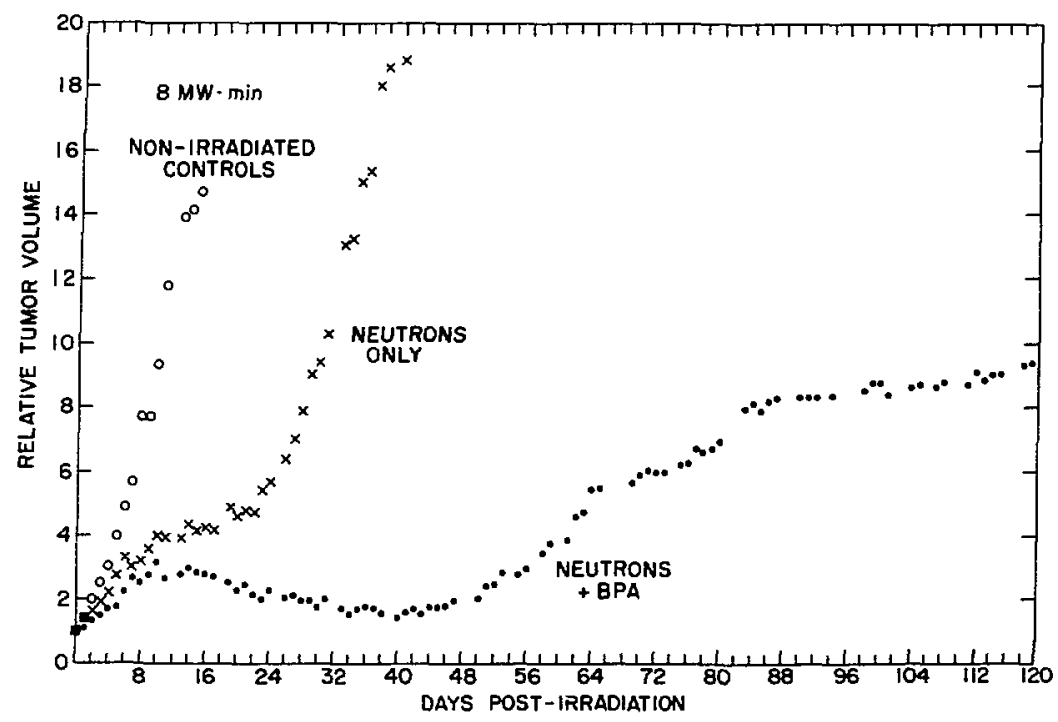

Fig. 4. BNCr at BMRR; neutron fluence $-6.7 \times 10^{12} \mathrm{n} / \mathrm{cm}^{-2}$. Experimental details as in Fig. 3, except: tumor dose, neutrons only $=624$ (rad $x$ (RBE); tumor dose, neutrons $+B P A$ $=2720$ ( $\mathrm{rad} \times \mathrm{RBE})$. Whole-body dose $=384$ ( $\mathrm{rad} \times \mathrm{RBE})$.

\section{Dose Fractionation in BNCT}

Conventional radiation therapy is given in multiple small doses in order that normal tissues within the treatment volume can repair sublethal damage. This assumes that normal tissues have a greater capactly for repair of such damage than malignant tissues.

Our demonstration of the ability to produce complete and permanent tumor regression of the murine melanoma implanted subcutaneously on the thigh with a single BPA/BNCT treatment enables us to utilize this model for testing the effects of dose fractionation on the effectiveness of BNCT. To date, one experiment has been carried out. All mice recelved $15 \mathrm{mg}$ of $10_{B-L}-B P A$ orally $6 \mathrm{~h}$ prior to irradiation. Group 1 recelved BPA followed by $6 \mathrm{MW}-\mathrm{min}$ of neutron irradiation. Group 2 received $B P A$ and $3 \mathrm{lW}-\mathrm{min}$, then 2 days later, another full dose of BPA and another $3 \mathrm{MW}-\mathrm{min}$. The results :

$$
\begin{array}{llll}
\text { Group } 1(6 \mathrm{HW}-\mathrm{min}) & 0 / 6 & \text { complete regression } \\
\text { Group } 2(3+3 \mathrm{MW}-\mathrm{mIn}) & 4 / 6 & \text { complete regression }
\end{array}
$$




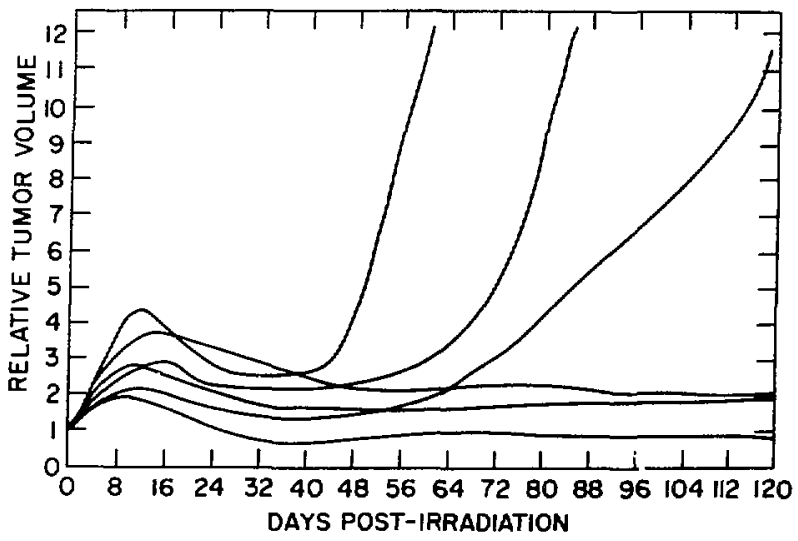

Fig. 5. Individual tumor grow th curves from neutrons + BPA group shown in Fig. 4. of 6 tumors treated, 3 eventually grew, 3 were controlled. Average of 6 lines shown produced neutrons + BPA line in Fig. 4 .

These results are preliminary, but the greater sfectiveness of the fractionated therapy may be due to the killing of cells in the second irradiation that were somehow missed during the first irradiation. This could be due to a non-uniform boron distribution within the tumor or perhaps to the presence of a latent cell pool.

Boron-containing compounds that show affinity for a wide variety of tumors (such as boronated porphyrins or antibodies) would be ideal for BNCT, but efforts to develop such compounds have not yet been able to demonstrate biological efficacy. It may be that BNCT of a particular type of tumor will require the identification and development of boron-containing compounds with specific affinity for that tumor; such affinity may also provide for favorable distribution within the tumor. BPA is demonstrably the first example of such a compound. As an analog of a melanin precursor, BPA selectively delivers boron to murine melanoma, eapecially to rapidly growing areas of the tumor, making it possible to obtain ratios of boron in tumor to that in normal tisaues in the range of 5 to 15 . To our knowledge, such selective accumulation in tumor of a systemically applied boronated compound has not been reported. NCT with the sulfhydryl borane BSH is based pri- 
marily on its exclusion from normal brain by the blood-brain barrier, rather than by selective binding. However, high blood boron concertrations from BSH present obvious problems, as it is believed that damage to normal tissue blood vesseis is a limiting factor in radiotherapy of brain tumors (Sweet, 1986; Moustafa, 1980).

Investigators in Japan have described the enhanced killing effect of thermal neutrons on melanoma cells in vitro that had been preincubated with BPA (Ichihashi, 1982; Itsumi, 1986).

Mishima (1983) has described the use of BPA to effect the apparent cure of a spontaneously occuring melanoma in a Duroc pig and to suppress the growtil of the Green melanoma in hamsters, following a single thermal neutron treatment. In the pig experiment, the BPA was administered via two peri-lesional injections at $19 \mathrm{~h}$ and 20 min beforc the irradiation. Mishima has recently carried out the first BNCT treatment of human melanoma using BPA (described at this Workshop), initial results are encouraging.

We have shown that BPA has little or no affinity for either a mammary adenocarcinoma (Coderre, 1987) or the KHJJ murine mamnary tumor carried in $B A L B / c$ mice (unpublished deta). In terestingly, preliminary results indicate that $B P A$ does accumulate significantly in a poorly pigmented B-16 melanoma carried in C57Bl mice (unpublished data). This observation implies that BPA uptake is dependent upon amino acid transport and not upon melanin synthesis. Human melanoma metastases vazy significantly in degree of pigmentation (Watts, 1981). If BPA can accumulate in both pigmented and non-pigmented metastatic sites, the chances for successful BNCT will be greatly enhanced.

\section{REFERENCES}

Asbury, A. K., Ojemann, R. G., Nielsen, S. L., and Sweet, W. H., 1972, Neuropathologic study of fourteen cases of malignant brain tumor treated by boron-10 slow neutron capture radiation, J. Neuropathol. Exp. Neurol., 31:278.

Beckurts, K. H., and Hirtz, K., 1964, SImultaneous thermal and epithermal foll activation, in: "Neutron Physics," Springer-Verlag, New York.

Coderre, J. A., Glass, J. D., Fairchild, R. G., Roy, U., Cohen, S., and Fand, I., 1987, Selective targeting of boronophenylalanine to melanoma for neutron capture therapy, Cancer Research, 47:6377.

Falrchild, R. G., and Goodman, L. J., 1966, Development and dosimetry of an "epithermal" neutron beam for possible use in neutron capture therapy. II. Absorbed dose measurements in a phantom man, Phys. Med. Biol., 11:15. 
Farr, L. E., Sweet, W. H., Robertson, J. S., Foster, C. G., Locksley, H. B., Sutherland, D. L., Mendelson, M. L., and Stickley, E. E., 1954, Neutron capture therapy with boron in the treatment of glioblastoma multiforme, Am. J. Roentgenol., 71: 279 .

Fukuda, H., Kobayashi, T., Matsuzawa, T., Kanda, K. , Ichihashi, M., and Mishima, Y., 1987, RBE of a thermal neutron beam and the $10_{B}(n, \alpha) 7_{L i}$ reaction on cultured $B-16$ melanoma cells, Int. J. Radiat. Biol., 51:167.

Gabel, D., Falrchild, R. G., Borner, H. G., and Larsson, B., 1984, The relative biological effectiveness in V79 Chinese hamster cells of the neutron capture reaction In boron and nitrogen, Radiat. Research, 98:307.

Godel, J. B., 1960, Degcription of facilities and mecharical components, Medical Research Reactor (MRR), Brookhaven National Laboratory Report No. BNL-600, Upton, NY.

Goodwin, J. T., Farr, L. E., Sweet, H. H., and Robertson, J. S., 1955, Pathological study of eight patients with glioblastoma multiforme treated by neutron capture therapy using boron-10, Cancer, 8:601.

Ichihashi, M., Nakanishi, T., and Mishima, Y., 1982, Specific kiling effect of $10_{B_{1} \text {-paraboronophenylalanine in thermal }}$ neutron capture therapy of malignant melanoma: in vitro radiobiological evaluation, J. Invest. Dermatol., $\frac{18015}{78: 215}$ Itsumi, H., Ichihashi, M., Funasaka, Y., Mishima, Y., Ikushima, T., Kobayashi, T., and Kanda, K., 1986, Potentially lethal damage repair of $\mathrm{B}-16$ melanoma cells pretreated with $10_{\mathrm{B}_{1}}$ paraboronophenylalanine after exposure to thermal neutron radiation, in: "Neutron Capture Therapy," H. Hatanaka, ed., Nishimura Co., Ltd., Ni igata.

Locher, G. L., 1936, Blological effects of therapeutic possibili- ! ties of neutrons, Am. J. Roentg. Radium Ther., 36:1.

Mishima, Y., 1980, Japanese Patent Request, Public Disclosure No. $122720-1980$.

Mishima, Y., Ichihashi, M., Nakanishi, T., Tsiy1, M., Ueda, M., Nakagawa, T., and Suzuki, T., 1983, Cure of malignant melanoma by single thermal neutron capture treatment using melanoma-seeking compounds, Proc. lst Int. Symp. on Neutron Capture Therapy, Brookhaven National Laboratory Report No. 51730 .

Moustafa, H. F., and Hopewell, J. W., 1980, La te functional changes in the vasculature of the rat brain after local x-irradiation, Br. J. Radiol., 53:21.

Robertson, J. S., Fairchild, R. G., and Atkins, H. L., 1972, Dosimetry of californium-252, Radio1., $104: 393$.

Rofstad, E. K., and Brustad, T., 1985, Tumor growth delay following single-dose irradiation of human melanoma xenografts. Correlations with tumor growth parameters, vascular structure, and cellular radiosensitivity, BI. J. Cancer, $51: 201$. 
Soloway, A. H., Wright, R. L., and Messer, J. R., 1961, Evaluetion of boron compounds for use in neutron capture therapy of brain tumors. I. Animal investigations, J. Pharmacol. Exp. Ther., 134:117.

Sweet, W. H., 1986, Medical aspects of boron slow neutron capture therapy, Brookhaven National Laboratcry, Report No. 51994.

Taylor, H. J., and Goldhaber, M., 1935, Detection of nuclear disintegration in a photographic emulsion, Nature, London, $135: 341$.

Hatts, K. P., Fairchild, R. G., Slatkin, D., Greenberg, D., Packer, S., Atkins, H. L., and Hannon, S. J., 1981, Melanin content of hamster tissues, human tissues and various melanomas, Cancer Research, 41:467.

\section{DISCLAIMER}

This report was prepared as an account of work sponsored by an agency of the United States Government. Neither the United States Goverament nor any agency thereof, nor any of their employees, makes any warranty. express or implied, or assumes any legal liability or responsibility for the accuracy, completeness, or usefulness of any information, apparatus, product, or process disclosed, or represents that its use would not infringe privately owned rights. Reference herein to any specific commercial product, process, or service by trade name, trademark, manufacturer, or otherwise does not necessarily constitute or imply its endossement, recommendation, or favoring by the United States Government or any agency thereof. The views and opinions of authors expressed herein do not necessarily state or reflect those of the United States Government or any agency thereof. 